\title{
Orals is dit stil
}

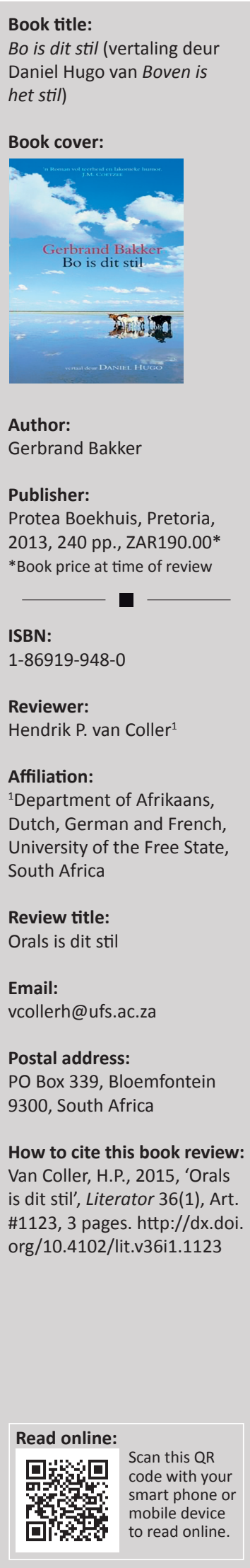

Gerbrand Bakker is 'n Nederlandse skrywer wat in 2006 debuteer met die roman, Boven is het stil, 'n werk wat baie lof inoes en benoem word vir meerdere literêre pryse soos die prestigieuse Libris Literatuurprys in 2007. Dit word wel bekroon met die Debutanten Prijs (2006) en die Gouden Ezelsoor (2006). In 2010 verwerf dit ook die IMPAC Dublin Literary Award, wat beskou word as een van die belangrikste internasionale literêre pryse en wat in die verlede toegeken is aan vooraanstaande skrywers, waaronder selfs enkele Nobelpryswenners. Inmiddels het daar ook 'n filmweergawe die lig gesien met die bekende Nanouk Leopold as regisseur. In 2013 verskyn hierdie roman in 'n Afrikaanse vertaling deur Daniel Hugo met die titel Bo is dit stil.

Bo is dit stil, wat afspeel op 'n Noord-Nederlandse plaas, sou op die eerste sig geklassifiseer kon word as 'streekliteratuur' wanneer Van Gorp se definisie daarvan as rigsnoer geneem word. Dit gaan hier naamlik inderdaad om 'n skilderagtige beskrywing van die landelike lewe, die bepalende invloed van die ruimte, generasiekonflik én ondergang van die boerebestaan - almal kenmerke van hierdie subgenre wat gelys word in Van Gorp se bekende literatuurleksikon. Boonop lyk dit asof dit alles beskrywe word met ' $n$ 'milde realisme', nóg een van die kenmerke van streekliteratuur en veral dan die 'sagte' variant daarvan. J.M. Coetzee se woorde wat op die omslag verskyn, "n Roman vol teerheid en lakonieke humor', laat blyk dat ook hy hierdie roman só sien.

In Afrikaans staan streekliteratuur bekend as 'plaasromans' wat hierdie roman van Bakker inderwaarheid ook is (Hugo vertaal dit egter as 'streekromans', bv. op bl. 30). En net soos by streekromans in Nederlands is daar 'n 'sagte' en 'harde' variant. Eersgenoemde is werke soos Oupa Landman se viool (Joubert 1955), Die uur van verlange (De Klerk 1953) en die liriese gedeeltes in verskeie romans van D.F. Malherbe en C.M. van den Heever. Van den Heever (1939) se beroemde roman Laat vrugte neig al na die harde variant, maar dit is veral die moderne Afrikaanse plaasroman waarin mildheid, sagte romantiek en liriese intermezzo's ver te soek is. Een van die beste voorbeelde van die 'harde' variant is Marlene van Niekerk (2004) se roman Agaat, maar dit is reeds volledig aanwesig in Karel Schoeman se novelle van 1969 ' $n$ Lug vol helder wolke.

Bo is dit stil is wat gebeure én fokus betref, dikwels hard en meedoënloos, en nugtere afstandelikheid (selfs onbetrokkenheid) én wreedheid kom ewe veel voor as teerheid. Ook die humor is meer dikwels wrang as lakoniek. Die beskrywing van hoe die sterwende vader 'n ereksie kry wanneer sy seun hom was (bl. 33), die sterwende ou man 'n appel verslind omdat sy seun hom geen ander kos gee nie (bl. 61), die besoeker Henk deur 'n kraai aangeval word (bl. 164, 165), die twee bure betrap word dat hulle mekaar met verkykers bespied (bl. 127), én die absurde poging van die ek-verteller om 'n skaap te red (waardeur hy byna verdrink, bl. 171, 172) ressorteer waarskynlik onder 'humoristiese' beskrywings sonder dat daar egter sprake is van enige versagting, deernis of lakonisme. Die beroemde openingsin is dalk 'n goeie voorbeeld:

Ik heb vader naar boven gedaan. Het bed heb ik uit elkaar gehaald, nadat ik hem in een stoel had gezet. Hij bleef in de stoel zitten als een kalf van een paar minuten oud, nog voor het schoongelikt is; met een ongestuurd wankelend hoofd en ogen die zich nergens aan hechten.

Nie net is die fel realistiese beskrywing so reg uit die plaasmilieu treffend nie, maar ook die wyse waarop die vader gedepersonaliseer word as 'n objek wat geen sê meer het nie. Dit word veral opgevang in die bewuste keuse van die verteller vir die perfektum in die openingsinne met die onafwendbare band: verlede/ hede én deur die keuse van die werkwoord 'doen' (en nie byvoorbeeld 'verschuiven' of 'verplaatsen' nie).

Die storiegegewe is relatief eenvoudig. Wanneer die vertelling begin, is Helmer van Wonderen 55 jaar oud. Hy woon by 'n klein melkboerdery in Noord-Holland met 20 koeie, 23 skape en twee donkies. Veral oor laasgenoemde is hy erg, omdat hy hulle self gekies en gekoop het; die res

Copyright: (C) 2015. The Authors. Licensee: AOSIS OpenJournals. This work is licensed under the Creative Commons Attribution License. 
het hy geërf. Saam in die huis woon sy sterwende vader van oor die tagtig, vroeër 'n tirannieke man; nou stiller en milder. Helmer is een van 'n identiese tweeling, maar sy broer, Henk, is dood op 'n jong ouderdom toe sy destydse vriendin, Riet, 'n ongeluk veroorsaak het deur van 'n dyk af te ry en Henk verdrink het. Ook die sagte en onderdrukte moeder is al 'n tyd gelede oorlede aan ' $n$ hartaanval. Helmer is nie ' $n$ tipiese boer nie; eerder ' $n$ romantiese dromer wat daarna hunker om Denemarke eendag te besoek. Aanvanklik was hy 'n paar maande lank 'n taalstudent in Amsterdam, maar na Henk se dood moes hy boer en só die plek inneem van sy gestorwe broer, die eintlike gunsteling van sy vader.

Sy besluit om sy pa na die boonste kamer toe te skuif is 'n belangrike motoriese moment wat baie dinge in beweging bring. Dit sinjaleer Helmer se besluit om self beslissings oor sy eie lewe te neem; dit skep afwagting by die leser oor die lot van sy vader én sy ietwat onbeholpe pogings om sy kamer te omskep tot ' $n$ gesellige ruimte met ' $n$ bed 'wat vir twee bedoel is' soos die inmengerige buurvrou (met ' $n$ ogie op hom) opmerk, en dui op sy hunkering na iemand in sy lewe. Helmer ontvang 'n brief van Riet, Henk se vroeëre geliefde, wat hom besoek en later haar seun - óók Henk genoem - na Helmer stuur as plaashulp sodat hy sy eie lewe op die regte spoor kan kry.

Sonder om alles te verklap is dit duidelik dat sy koms 'n verdere katalisator is. Waar Henk se probleme tipies is van dié van 'n karakter in 'n ontwikkelingsroman, spieël Helmer se eie worsteling met 'n onverwerkte verlede dié van Henk. Die verhouding van Helmer met die jong Henk is ook in baie opsigte uiters verwikkeld en dit herinner in bepaalde opsigte aan dié met sy gestorwe tweelingbroer. Verdronge gevoelens en herinneringe herleef en gee aanleiding tot ' $n$ stel keuses wat Helmer se lewe in nuwe bane stuur.

Resensente maak gewag van die manier waarop die ekspreker in groot besonderhede beskrywe hoe die bome gesnoei word, daar gemelk word én hoe hy Henk en Riet afgekyk het terwyl hulle seksueel verkeer het. Dit wek die skyn van openhartigheid, maar daar is talle voorbeelde waaruit blyk dat die ek-verteller ook terughoudend en selfs behoedsaam is en dinge wegsteek. Die belangrikste motief wat in hierdie verband genoem kan word, is dié van (homo) seksualiteit. Vrouens word in algemene terme beskrywe as 'amper net so lelik' soos ma (bl. 26) of steeds aantreklik '[s]y het jeans aan. Haar hare is nog altyd blond ...' By die herinneringe aan mans of die beskrywing van hulle is dit opvallend hoe liggaamlikheid voorop staan: '[ $d]$ it is asof ek die plaashulp op my boude voel' (bl. 59); hy verwys dikwels na die soepelheid van die jong melklorriedrywer én sy jong besoeker, Henk, die seun van Riet (bl. 133), ‘[s]y halfkaal lyf hier in die klein kamertjie is vir my te veel' (bl. 149) en 'ek sien hoe die spiere in sy nek tril' (bl. 153), om maar net enkele voorbeelde te noem. Hy suggereer ook op talle plekke dat hy seksueel aangetrokke was tot sy gestorwe broer. Vergelyk sy opmerking: 'En ek wonder steeds na wie ek daardie nag gekyk het' (bl. 126), wat sy seksuele opwinding toe hy na Henk en Riet gekyk het, in 'n heel ander lig plaas.
Uit die opmerking dat hy glad nie na 'daardie meisie' (Riet) gekyk het nie (bl. 143), blyk sy onbetrokkenheid by haar. Sy negatiewe gevoel jeens haar spruit ook uit die feit dat sy sy verhouding met Henk vernietig het én boonop verantwoordelik was vir sy dood. Uit die woorde van die sterwende vader, 'Jy het ook geweldig vir jou broer omgegee. Geweldig baie' en 'Nee [...] ek het dit vermoed. En ek wil nooit weer iets daarvan hoor nie' (bl. 176), blyk dat die vader hom veel beter geken het as wat hy ooit vermoed het.

Bo is dit stil het 'n veelbetekenende titel, want 'bo' verwys na die bokamer waarheen die ek-spreker sy sterwende pa verskuiwe en waar hy nie net stil is omdat hy dikwels slaap nie, maar ook tot stilte gemaan word deur die seun wat byvoorbeeld aan sekere besoekers voorgee dat die vader reeds dood is. Maar 'stilte' kenmerk bykans die hele bestaan op die plaas: 'bo is dit stil [...] dit is nie net bo stil nie, dit is oral stil' (bl. 102). 'Bo' verwys egter ook na die hiernamaalse ruimte / die hemel, 'die plek daarbo' (bl. 89, 110). En juis hulle wat 'bo' is (soos die tweelingbroer, Henk en die moeder), is bykans 'n lewende teenwoordigheid in die huis: die moeder se gelaatsuitdrukking op haar foto word deur die ek-verteller agtereenvolgens geïnterpreteer as afsydig, hooghartig, afkeurend asof sy steeds sy gedrag beoordeel. Ook die gestorwe tweelingbroer, Henk, is dalk 'stil' omdat hy dood is, maar is as afwesige persoon moontlik een van die belangrikste karakters in die roman.

'n Mens lees nooit boeke met 'n tabula rasa-bewussyn nie; jou (literêre) verwagtings is gevorm deur baie dinge, onder andere ander tekste wat op konnotatiewe wyse aansluit by die spesifieke teks wat jy lees of selfs intertekstueel daarmee verband hou. Vir die Afrikaanse leser is twee van sodanige tekste die genoemde Agaat en die novelle ' $n$ Lug vol helder wolke (kyk Van Niekerk 2004; Schoeman 1969). Marlene van Niekerk (2004) se teks is ook 'n teks van 'n sterwende persoon wat tiranniek was, óók een waarin wreedheid en deernis; empatie en haat deurmekaar loop en waarin ' $n$ verlede broksgewys onthul word. Die Schoeman-teks (1969) is selfs 'n sterker interteks. Dit begin immers met die woorde: '[d]ie middae is stil ...'. Ook hier is die natuur oorheersend en die mens ondergeskik aan die veranderinge van seisoene. Kobus het ook gaan studeer, moes ook in die spore van 'n gestorwe broer (die vadere se oogappel) tree en ook teësinnig boer. Net soos Helmer verlang hy na 'n ander romantiese ruimte, is hy aseksueel of homoseksueel en verkoop hy ook oplaas die plaas om iets van sy drome te bewaarheid.

In baie opsigte is Bo is dit stil verwant aan die moderne Afrikaanse plaasroman met die duidelike afstandname van erfopvolging, die implisiete kritiek op die hiërargiese (feodale) stelsel wat heers op 'n tipiese plaas waarin vrou en kinders en arbeiders onderdruk word en die verset teen die naïewe wyse waarop die natuurbestaan verheerlik word in ouer Nederlandse plaasromans. Bakker se tweede roman (die werklike toetssteen vir 'n skrywer) speel ook af in NoordHolland en kan weer as 'n plaasroman bestempel word is. Hierdie roman is nie goed ontvang nie en 'n vooraanstaande resensent het dit selfs 'ontstellend saai' genoem. 
Hugo se vertaling is goed. Uiteraard sou 'n mens ook oor bepaalde woordkeuses kon kibbel (kyk bl. 30: 'streekroman'), waar ons eerder 'plaasroman' sou verwag; op bladsy 71 is dit asof 'slaptjipsstalletjie' bepaald uit sy plek klink: Nederlandse friete is ver van slap; bladsy 79: "n denim' klink iets beter as 'jeans'; bladsy 104: 'gedrag saamgaan met ...', is vreemd gestel; bladsy 128 en 216: 'botterkoek' is 'short bread' of 'brosbrood'; bladsy 132: 'fan' pas nie in die sprekersregister nie; bladsy 135: 'kokhalsend' is ietwat argaïese Afrikaans; bladsy 154: 'vrieskis' sou dalk eerder 'vrieskas' kon wees; bladsy 155: 'plaashulp' klink té Nederlands; bladsy 182: 'rondgehang' sou eerder 'rondgedrentel' kon wees; en bladsy 236: 'trampoliens' [...] is nog 'onbespring' klink raar. Soms gaan subtiliteite verlore (kyk slegs na die openingsin), maar in die geheel slaag hy goed daarin om die Nederlandse sfeer te behou.
Die treffende slotsin 'Ek is alleen' staan nie meer in die teken van ' $n$ eensaamheid wat verskrikkend is nie. Hoe dit sover gekom het, is iets wat die leser liefs self moet ontdek. Na my gevoel is die roman as geheel geen meesterstuk nie - die slotgedeelte van die roman (met sy deus ex machina verskyning van 'n vorige karakter) is na my gevoel swakker as die res - maar meer as beslis die lees werd. Soos die Nederlanders sê: een aanrader.

\section{Literatuurverwysings}

Bakker, G., 2006, Boven is het stil, Uitgeverij Cossee, Amsterdam. De Klerk, W.A., 1953, Die uur van verlange, NB Uitgewers, Kaapstad. Joubert, G.J., 1955, Oupa Landman se viool, Nasionale Boekhandel Bpk., Kaapstad. Schoeman, K., 1969, 'n Lug vol helder wolke, Human \& Rousseau, Kaapstad. Van den Heever, C.M., 1939, Laat vrugte, Nasionale Pers, Bloemfontein. Van Niekerk, M., 2004, Agaat, Tafelberg Uitgewers, Kaapstad. 